\title{
Assessment of Skills Needed of A Craftsman In Servicing, Maintaining And Repairing Of Mechanical Plants In Building Industry In Rivers State.
}

\author{
Deebom, MtormaBari TamBari \\ Department of Vocational and Technology Education, \\ Rivers State University, Port Harcourt \\ Dr. Dokubo, Isaac Nwojiewho \\ Department of Vocational and Technology Education, \\ Rivers State University, Port Harcourt
}

\begin{abstract}
This study examines the assessment of skills needed of a craftsman in servicing, maintaining and repairing of mechanical plants in building industry in Rivers State. One research question guided the study while two hypotheses were formulated and tested at 0.05 level of significance. Descriptive survey research design was used and the population of the study was 172 respondents from technical colleges in Rivers State. A sample of 172 respondents ( 29 teachers and 143 students) was used for the study. The data for analysis was collected through a self-constructed instrument titled "Assessment of Skills Needed by Mechanical Craftsman Questionnaire" (ASNMCQ) which was properly validated. A reliability coefficient was established for the instrument through Cronbach Alpha method whose coefficient was 0.84 . The research questions were analysed using descriptive statistics of mean with standard deviation while hypotheses were tested with z-test. The study revealed that testing the properties of metals, marking out, metal heat treatment, drilling operations and metal scrapping and lapping are operational skills needed by craftsman for the servicing, maintaining and repairing of plants. It was recommended amongst others that NABTEB and similar examination bodies could consider using assessing students' practical skills at NTC level as a criterion for awarding of certificate to mechanical engineering trades students.
\end{abstract}

Keywords: Craftsmen, Maintaining, Mechanical plants, Repairing, Servicing and Skills

\section{INTRODUCTION}

Technical and Vocational Education and Training (TVET) programmes are offered for the purpose of producing skilled manpower required for the nation's economic and technological development (Federal Republic of Nigeria [FRN], 2009). In the Nigerian educational system, technical colleges' curriculum has practical skills content up to $60 \%$ (National Board for Technical Education [NBTE], 2003). After graduation students are expected to acquire these practical skills to enable them create or secure sustainable jobs and use their knowledge, abilities, initiative and creativity for self-reliance. This is in line with the 2001 United Nation Educational, Scientific and Cultural Organization (UNESCO) and International Labour Organization's (ILO)

General Conference on TVET. They referred to TVET as those aspects of the educational process involving, in addition to general education, the study of technologies and related sciences, and the acquisition of practical skills, attitudes, understanding and knowledge related to occupations in various sectors of the economic and social life (UNESCO \& ILO, 2002). 
Mechanical engineering trades is one of the TVET programmes in technical colleges in which students are examined by the National Business and Technical Examination Board (NABTEB) based on the NBTE curriculum for the award of National Technical Certificate (NTC). The TVET programmes on mechanical engineering trade and building trade among others are aimed at training and imparting necessary skills leading to the production of craftsmen who will be selfreliant and enterprising in job areas such as metal fitting, machining, builders etc (NBTE, 2003).

Dokubo (2017) opined that maintenance, servicing and repairing are activities geared towards ensuring that plants and devices are in a functional and good working conditions as specified by the manufacturer. In carrying out these exercises, the craftsman must be equipped and knowledgeable with the three domain of learning which is referred to as the 3-Hs rather than the 3-Rs of Reading, Writing and Arithmetic. The 3-Hs (Cognitive-Head, Affective-Heart and Psychomotor-Hand) are practically applicable in maintaining, servicing and repairing of mechanical plants. This also requires special operational skills such as knurling, piping and fitting, machining, milling, turning, drilling, welding and fabrication operation etc.

The psychomotor aspect of mechanical engineering trade objectives is meant to achieve adequate development in skills which can make the student (craftsman) service, maintain and repair mechanical related appliance. NABTEB uses a marking scheme checklist to assess students' practical skills in NTC mechanical engineering trades examinations. The scheme does not in detail highlight the various stages of specific operational skills involved in the process of carrying out the task given. To buttress this point, Ombugus (2013) asserted that the assessment of skills used by NABTEB and technical teachers only help to determine students' achievement of mechanical engineering trade objectives in cognitive, affective and psychomotor domains. This was observed in Ming (2010) that there are negligible observable results in achievement of psychomotor domain in technical colleges. The practical skills assessments conducted by NABTEB and teachers are mere product rating and not skills manipulation rating of craftsman (Williams, 2012; Okwelle \& Okeke, 2012). This method has limitation, according to Ombugus and Ogbuanya (2014), due to its inability to assess the process of carrying out tasks and operations involved. The implication of this is that the scores and grades assigned to students in practical works by the teachers may not be true representative of their performance and though the students will be given certificates but without adequate practical skills that will enable them maintain, service and repair appliance as well as creating and secure sustainable job. Hence it is necessary to develop a valid and reliable performance base assessment instrument that will contain the details of the operational skills best for employment. This study is delimited to metal fitting work of mechanical engineering trade.

Fitting means preparing mating parts to touch or join each other in such a way that one will turn inside another or slide upon another or the parts will hold tightly together so that they cannot move upon each other (Okoro, 2008). Metal Fittings are tasks necessary to make metal parts fit. It involves practical skills operations in measurement, marking-out, clamping, cutting, scrapping and lapping, filing and finishing, drillings, grinding, assembling etc to repair, maintain or produce mechanical component. The practical skills acquired in metal fitting enables technical colleges' graduates (craftman) to secure and sustain a job in mechanical engineering trade (Adamu, Dawha \& Kamar, 2015).

\section{Statement of the Problem}

The Federal Government of Nigeria in her National Policy on Education (NPE, 2005) planned on developing the technical manpower needed in the engineering sector such as the engineers, 
technologists, technicians and craftsmen as the bedrock to the nation's building. The manpower will pass through technical college, polytechnics or universities to acquire the skills or knowledge and sometime a well organized private workshop. The nation can only developed to the standard of technological advancement it deserve only when the bedrock (craftsman) is properly guided, secured and guaranty by the government to prove their skills or knowledge that will in-turn promotes the living standard of the nation in terms of production and training. To achieve these objectives, well equipped training workshops, adequate training materials and facilities are needed in organized training centre and institutions. Also, qualified technical instructors that will assess the craftsman in terms of skills acquired to measure up with the ones that needed for maintaining, servicing and repairing of plants in building industry upon completion of the training.

To assess the students (craftsman) skills, NABTEB uses a marking scheme checklist to assess students' practical skills in NTC mechanical engineering trades examinations. The scheme does not in detail highlight the various stages of specific operational skills involved in the process of carrying out the task given. To buttress this point, Ombugus (2013) asserted that the assessment of skills used by NABTEB and technical teachers only help to determine students' achievement of mechanical engineering trade objectives in cognitive, affective and psychomotor domains. This was observed in Ming (2010) that there are negligible observable results in achievement of psychomotor domain in technical colleges. The practical skills assessments conducted by NABTEB and teachers are mere product rating and not skills manipulation rating of craftsman (Williams, 2012; Okwelle \& Okeke, 2012). This method has limitation, according to Ombugus and Ogbuanya (2014), due to its inability to assess the process of carrying out tasks and operations involved. The implication of this is that the scores and grades assigned to students in practical works by the teachers may not be true representative of their performance and though the students will be given certificates but without adequate practical skills that will enable them maintain, service and repair appliance as well as creating and secure sustainable job. This prompted the study on assessment of skills needed of a craftsman in servicing, maintaining and repairing of mechanical appliance as the problem statement.

\section{Purpose of the Study}

The purpose of this study is to examine skills needed of a craftsman in servicing, maintaining and repairing of mechanical plants in building industry in Rivers State.

\section{Research Question}

The following question was answered to guide the study.

1. What are the practical skills needed of a craftsman in servicing, maintaining and repairing of mechanical plants in building industry?

\section{Hypotheses}

Two null hypotheses were formulated and tested at 0.05 level of significance.

1. There is no significance difference in the mean ratings of students and instructors on metal heat treatment skills needed by a craftsman in servicing, maintaining and repairing of mechanical plants in building industry?.

2. There is no significance difference in the mean ratings of students and instructors on marking out skills needed by a craftsman in servicing, maintaining and repairing of mechanical plants in building industry? 


\section{METHODOLOGY}

The design of the study is a descriptive survey research. Descriptive survey study is that in which the researcher collects data from a large sample drawn from a given population and describes certain features of the sample as they are at the time of the study and which are of interest to the researcher without manipulating any independent variables of the study (Nwankwo, 2013). This study was carried out in four technical colleges in Rivers State which are Government Technical College, Port Harcourt, Government Technical College, Ahoada, Government Technical College, Tombia and Government Technical College, Eleogu. The population of the study consisted of all the 172 teachers and students of mechanical engineering trades in technical colleges in Rivers State. As at the time of this study, technical colleges in Rivers State have 29 teachers and 143 students of mechanical trades (Source: NBTE Unit, Department of Statistics, Rivers State Ministry of Education, 2017). No sample was done due to the smallness of the population and hence no sampling technique. The instrument for the data collection was a self-constructed questionnaire titled "Assessment of Skills Needed by Mechanical Craftsman Questionnaire" (ASNMCQ). The instrument (ASNMCQ) which was divided into different sections based on operational skills and tasks was patterned after Likert5-point rating scale of Very Highly Needed (VHN-5), Highly Needed (HN-4), Moderately Needed (MN-3), Lowly Needed (LN-2) and Very Lowly Needed (VLN-1) respectively.

In order to establish the validity of the instrument, copies of the instrument were given to two experts in the Department of Vocational and Technology Education in Rivers State University, Port Harcourt for face and content validation. The reliability of the instrument (ASNMCQ) was established through test-retest method for measure of stability. Simple random sampling technique was used to draw 6 teachers and 14 students of mechanical engineering trades from Federal College of Education (Technical), Omoku for reliability test. Copies of the instruments were administered to the teachers and students. After an interval of one week, the same instrument was re-administered to the same group. The initial (test) and the re-test scores of the sample were correlated using Cronbach Alpha method. A reliability coefficient of 0.84 was established for instrument which was considered reliable. The administration of the instrument was done with the assistance of four teachers who were trained by the researcher as research assistants. Completed copies of the instrument (ASNMCQ) were collected for analysis. Data were analysed with descriptive statistics of mean and standard deviation while hypothesis was tested with z-test. Any item with mean of 3.00 and above was accepted while mean value less than 3.00 was rejected. For hypothesis, if the z-calculated is less than or equal to the critical value of $\mathrm{z}$, the null hypothesis is accepted otherwise reject.

\section{RESULTS AND DISCUSSION OF FINDINGS}

Research Question 1: What are the practical skills needed of a craftsman in servicing, maintaining and repairing of mechanical plants in building industry? 
Table 1: Mean Ratings of Teachers and Students on the Skills Needed of a Craftsman in Maintaining, Repairing and Servicing of Mechanical Appliances $\left(N_{1}=29 ; N_{2}=143\right)$

\begin{tabular}{|c|c|c|c|c|c|c|c|}
\hline \multirow[t]{2}{*}{ S/N } & \multirow{2}{*}{$\begin{array}{l}\text { Skills and Operations } \\
\text { Skill 1: Measurement }\end{array}$} & \multicolumn{3}{|c|}{ Teachers } & \multicolumn{2}{|c|}{ Students } & \multirow[b]{2}{*}{ Decision } \\
\hline & & $\mathbf{X}_{1}$ & $\mathrm{SD}_{1}$ & $\begin{array}{l}\text { Decisi } \\
\text { on }\end{array}$ & $\mathbf{X}_{2}$ & $\mathbf{S D}_{2}$ & \\
\hline 1 & Measuring a surface with a rule & 3.51 & 0.82 & $\mathrm{HN}$ & 4.52 & 0.64 & VHN \\
\hline 2 & $\begin{array}{l}\text { Measuring a surface with } \\
\text { inside/outside calipers }\end{array}$ & 3.32 & 0.62 & $\mathrm{MN}$ & 4.21 & 1.08 & $\mathrm{HN}$ \\
\hline 3 & Measuring with a micrometer & 3.65 & 0.57 & $\mathrm{HN}$ & 3.42 & 0.72 & MN \\
\hline 4 & $\begin{array}{l}\text { Measuring a depth with a } \\
\text { micrometer depth gauge }\end{array}$ & 3.14 & 0.54 & $\mathrm{MN}$ & 3.57 & 0.59 & $\mathrm{HN}$ \\
\hline \multirow[t]{2}{*}{5} & Measuring with gauges & 3.65 & 0.70 & $\mathrm{HN}$ & 3.87 & 0.34 & $\mathrm{HN}$ \\
\hline & $\begin{array}{l}\text { Average } \\
\text { Skill 2: Marking Out }\end{array}$ & 3.50 & 0.65 & HN & 3.92 & 0.67 & HN \\
\hline 6 & $\begin{array}{l}\text { Marking out parallel lines using a } \\
\text { combination set }\end{array}$ & 4.26 & 0.69 & HN & 4.04 & 0.66 & HN \\
\hline 7 & $\begin{array}{l}\text { Marking out angles using a } \\
\text { protractor }\end{array}$ & 4.52 & 0.59 & VHN & 4.70 & 1.09 & VHN \\
\hline 8 & $\begin{array}{l}\text { Marking out lines at right angles } \\
\text { to an angle }\end{array}$ & 3.82 & 0.59 & $\mathrm{HN}$ & 3.54 & 0.61 & HN \\
\hline \multirow[t]{3}{*}{9} & $\begin{array}{l}\text { Marking out angles using an } \\
\text { adjustable square }\end{array}$ & 4.73 & 0.70 & VHN & 4.03 & 0.78 & HN \\
\hline & Average & 4.33 & 0.64 & HN & 4.08 & 0.79 & HN \\
\hline & Skill 3: Clamping & & & & & & \\
\hline 10 & Clamping a stock with a hand vice & 4.78 & 0.81 & VHN & 4.08 & 0.56 & $\mathrm{HN}$ \\
\hline 11 & $\begin{array}{l}\text { Clamping an irregular stock with } \\
\text { a vee-block }\end{array}$ & 4.52 & 0.62 & VHN & 4.71 & 1.08 & VHN \\
\hline 12 & $\begin{array}{l}\text { Clamping a stock with a bench } \\
\text { vice }\end{array}$ & 3.09 & 0.58 & $\mathrm{MN}$ & 3.74 & 0.54 & HN \\
\hline \multirow[t]{2}{*}{13} & Clamping a stock with a leg vice & 3.63 & 0.85 & $\mathrm{HN}$ & 4.67 & 0.90 & VHN \\
\hline & $\begin{array}{l}\text { Average } \\
\text { Skill 4: Cutting }\end{array}$ & 4.01 & 0.72 & HN & 4.30 & 0.77 & $\mathbf{H N}$ \\
\hline 14 & $\begin{array}{l}\text { Cutting-off a stock with a } \\
\text { hacksaw }\end{array}$ & 3.97 & 0.91 & $\mathrm{HN}$ & 4.59 & 0.88 & VHN \\
\hline 15 & $\begin{array}{l}\text { Cutting-off a stock with a power } \\
\text { saw }\end{array}$ & 4.66 & 0.67 & VHN & 3.91 & 0.74 & $\mathrm{HN}$ \\
\hline 16 & $\begin{array}{l}\text { Cutting-off a stock with a } \\
\text { snip/hand shear }\end{array}$ & 3.90 & 1.08 & $\mathrm{HN}$ & 4.60 & 0.52 & VHN \\
\hline \multirow[t]{3}{*}{17} & $\begin{array}{l}\text { Cutting-off a stock with a power } \\
\text { shear }\end{array}$ & 3.33 & 1.05 & $\mathrm{MN}$ & 3.41 & 0.75 & $\mathrm{MN}$ \\
\hline & Average & 4.00 & 0.93 & HN & 4.13 & 0.72 & HN \\
\hline & Skill 5: Filing and Finishing & & & & & & \\
\hline 18 & $\begin{array}{l}\text { Filing-off a stock using a coarse } \\
\text { file }\end{array}$ & 3.30 & 0.85 & $\mathrm{HN}$ & 3.07 & 0.90 & MN \\
\hline 19 & Using a cold-chisel on metals & 4.63 & 0.85 & VHN & 4.67 & 0.90 & VHN \\
\hline 20 & Filing-off a stock with a flat file & 3.28 & 0.72 & MN & 3.62 & 1.03 & $\mathrm{HN}$ \\
\hline \multirow[t]{2}{*}{21} & $\begin{array}{l}\text { Filing-off a stock with a curved } \\
\text { file }\end{array}$ & 3.85 & 0.59 & $\mathrm{HN}$ & 3.80 & 0.80 & $\mathrm{HN}$ \\
\hline & $\begin{array}{l}\text { Average } \\
\text { Skill 6: Metal Scraping \& } \\
\text { Lapping }\end{array}$ & 3.80 & 0.75 & HN & 3.79 & 0.91 & HN \\
\hline
\end{tabular}




\begin{tabular}{|c|c|c|c|c|c|c|c|}
\hline 22 & $\begin{array}{l}\text { Lapping a stock with a lapping } \\
\text { machine }\end{array}$ & 3.42 & 0.87 & MN & 3.51 & 1.08 & $\mathrm{HN}$ \\
\hline 23 & $\begin{array}{l}\text { Scrapping-off a stock with a half- } \\
\text { round scrapper }\end{array}$ & 3.97 & 0.67 & $\mathrm{HN}$ & 4.58 & 0.62 & VHN \\
\hline \multirow[t]{3}{*}{24} & $\begin{array}{l}\text { Lapping a stock using a honing } \\
\text { machine }\end{array}$ & 4.56 & 1.13 & VHN & 3.54 & 0.71 & $\mathrm{HN}$ \\
\hline & Average & 4.00 & 0.89 & HN & 3.88 & 0.80 & HN \\
\hline & Skill 7: Metal Heat Treatment & & & & & & \\
\hline 25 & Annealing & 3.41 & 1.05 & MN & 3.53 & 1.11 & $\mathrm{HN}$ \\
\hline 26 & Hardening & 4.74 & 0.89 & VHN & 4.65 & 0.98 & VHN \\
\hline 27 & Normalizing & 4.14 & 0.75 & $\mathrm{HN}$ & 3.09 & 0.67 & $\mathrm{MN}$ \\
\hline \multirow[t]{3}{*}{28} & Tempering & 4.53 & 0.61 & VHN & 4.86 & 0.83 & VHN \\
\hline & Average & 4.21 & 0.83 & HN & 4.03 & 0.89 & HN \\
\hline & Skill 8: Soft and Hard Soldering & & & & & & \\
\hline 29 & $\begin{array}{l}\text { Soldering a stock using an } \\
\text { electric soldering bit }\end{array}$ & 4.72 & 1.03 & VHN & 4.10 & 0.69 & $\mathrm{HN}$ \\
\hline 30 & $\begin{array}{l}\text { Brazing a stock using oxy- } \\
\text { acetylene gas }\end{array}$ & 4.52 & 0.58 & VHN & 4.70 & 0.85 & VHN \\
\hline \multirow[t]{3}{*}{31} & $\begin{array}{l}\text { Soldering a stock using a blow } \\
\text { lamp }\end{array}$ & 3.81 & 1.15 & $\mathrm{HN}$ & 4.46 & 0.56 & $\mathrm{HN}$ \\
\hline & Average & 4.35 & 0.92 & HN & 4.42 & 0.70 & HN \\
\hline & Skill 9: Drilling Operations & & & & & & \\
\hline 32 & $\begin{array}{l}\text { Reaming a hole with a reaming } \\
\text { tool }\end{array}$ & 2.95 & 0.67 & MN & 3.71 & 1.13 & $\mathrm{HN}$ \\
\hline 33 & $\begin{array}{l}\text { Reaming a hole with a hand } \\
\text { reamer }\end{array}$ & 3.35 & 0.88 & MN & 4.53 & 0.65 & VHN \\
\hline 34 & Boring a hole with a boring tool & 3.82 & 1.04 & $\mathrm{HN}$ & 2.47 & 0.73 & $\mathrm{LN}$ \\
\hline 35 & Counter-boring operation & 2.36 & 0.87 & $\mathrm{LN}$ & 3.08 & 0.71 & MN \\
\hline \multirow[t]{3}{*}{36} & Counter-sinking operation & 4.10 & 1.11 & $\mathrm{HN}$ & 4.77 & 0.85 & VHN \\
\hline & Average & 3.32 & 0.91 & MN & 3.71 & 0.81 & HN \\
\hline & $\begin{array}{l}\text { Skill 10: Testing Metal } \\
\text { Properties }\end{array}$ & & & & & & \\
\hline 37 & Testing a stock for hardness & 3.91 & 1.08 & $\mathrm{HN}$ & 4.29 & 0.88 & $\mathrm{HN}$ \\
\hline 38 & Testing a stock for toughness & 3.07 & 0.85 & MN & 4.50 & 0.97 & VHN \\
\hline 39 & Testing a stock for ductility & 3.73 & 0.72 & $\mathrm{HN}$ & 3.09 & 0.86 & MN \\
\hline \multirow[t]{2}{*}{40} & Testing a stock for malleability & 4.64 & 1.11 & VHN & 3.74 & 1.02 & $\mathrm{HN}$ \\
\hline & Average & 3.84 & 0.94 & HN & 3.91 & 0.93 & HN \\
\hline
\end{tabular}

Source: Extract From Adamu, Dawha and Karma, 2015

KEY: Very Highly Needed (VHN-5), Highly Needed (HN-4), Moderately Needed (MN-3), Lowly Needed (LN-2) and Very Lowly Needed (VLN-1)

Table 1 show that the respondents accepted all the items listed in the table as various operational skills needed by craftsman in servicing, maintaining and repairing of mechanical plants in building industry? This is shown in the average mean.

\section{Test of Hypotheses}

The following null hypotheses were tested at 0.05 level of significance.

$\mathbf{H}_{\text {01 }}$ : There is no significance difference in the mean ratings of students and instructors on metal heat treatment skills needed by a craftsman in servicing, maintaining and repairing of mechanical plants in building industry?. 
Table 2: z-Test Analysis on Metal Heat Treatment Skills Needed by a Craftsman

\begin{tabular}{llllllll}
\hline Group & $\mathbf{N}$ & $\mathbf{X}$ & SD & df & zcal & Zcrit & Decision \\
\hline Teachers & 29 & 4.21 & 0.83 & & & & \\
Students & 143 & 4.03 & 0.89 & & & & \\
\multicolumn{2}{c}{ Source: Researchers' Field Survey, 2017 } & Accept Ho $_{\mathbf{0}}$ if Zcal < Zcrit, else Reject
\end{tabular}

The null hypothesis is accepted since Zcal (1.04) is less than zcrit (1.960). This implies that there is no significance difference in the mean scores of teachers and students on metal heat treatment skills needed by a craftsman in servicing, maintaining and repairing of mechanical appliances.

Ho2: There is no significance difference in the mean ratings of students and instructors on marking out skills needed by a craftsman in servicing, maintaining and repairing of mechanical plants in building industry?

Table 3: z-Test Analysis on Marking Out Skills Needed by a Craftsman

\begin{tabular}{llllllll}
\hline Group & $\mathbf{N}$ & $\mathbf{X}$ & SD & df & zcal & Zcrit & Decision \\
\hline Teachers & 29 & 4.33 & 0.64 & & & & \\
Students & 143 & 4.08 & 0.79 & & & & \\
\hline \multicolumn{2}{c}{ Source: Researchers' Field Survey, 2017 } & Accept Ho if Zcal < Zcrit, else Reject
\end{tabular}

The null hypothesis is accepted since zcal (1.81) is less than zcrit (1.960). This implies that there is no significance difference in the mean scores of teachers and students on marking out skills needed by a craftsman in servicing, maintaining and repairing of mechanical plants in building industry?

\section{DISCUSSION OF FINDINGS}

The result of the study reveal that testing the properties of metals, marking out, metal heat treatment, drilling operations and metal scrapping and lapping are operational skills needed by craftsman for the servicing, maintaining and repairing of plants in building industry?. This finding is in agreement with Iji in (Adamu, Dawha \& Kamar, 2015) who asserted that skills in mechanical engineering trades such soft and hard soldering, clamping, measurement and drilling operation skills are needed by any mechanical professional (engineers, technologists, technician, craftsmen) for survival in the profession and also for job security.

\section{CONCLUSION}

To produce a skilled manpower of craftsman in mechanical trades that can secure and sustain their jobs, it requires a reform of assessment processes of various skills that are needed. These skills are mostly needed especially in servicing, maintaining and repairing of mechanical plants in building industry?

\section{RECOMMENDATIONS}

1. Mechanical engineering trade teachers in technical colleges and similar skills acquisition institutions should be made to be aware on the importance of assessing students' practical skills on the programme.

2. NABTEB and similar examination bodies could consider using assessing students' practical skills at NTC level as a criterion for awarding of certificate to mechanical engineering trades students. 


\section{References}

Adamu, E. Y, Dawha, J. M. \& Kamar, T. S. (2015). Development and Validation of Mechanical Engineering Trade Skills Assessment Instrument for Sustainable Job Security in Yobe State. Journal of Education and Practice, 6 (16), 6-9.

Dokubo, I. N (2017). Empowering the $21^{\text {st }}$ century building technology students through entrepreneurship education. American journal of engineering research. 6 (12), 148 - 154

Federal Republic of Nigeria (2009). National policy on Education (5th Edition). Lagos: NERDC Press.

National Board for Technical Education (2003). Mechanical Engineering Craft Curriculum and Module Specifications: National Technical Certificate (NTC) and Advanced National Technical Certificate (ANTC). UNESCO - Nigeria Project. Retrieved from http://www.unesdo.unesco.org/images/0016/001613/161353e.pdf. and Accessed 11/2/2017.

Nwankwo, O.C. (2013). A Practical Guide to Research Writing for Students of Research Enterprise (5 ${ }^{\text {th }}$ Ed). PortHarcourt: University of Port-Harcourt Press Ltd.

Okoro, O. M. (2008). A Manuscript on Evaluation in Vocational Teacher Education. Department of Vocational Teacher Education, University of Nigeria, Nsukka.

Ombugus, D. A. (2013). Development and Validation of Workshop-based Process Skill Test in Mechanical Engineering Craft for Assessing Students Skills in Technical Colleges in Nasarawa State, Nigeria.Unpublished Ph.D Thesis Submitted to the Department of Vocational Teacher Education, University of Nigeria, Nsukka.

Ombugus, D.A. \& Ogbuanya,T.C. (2014). Development and Validation of Workshop-based Process Skill Test in Metal Fitting for Improving Students' Skills in Technical Colleges for Work. Journal of Education and Practice, 5(23), 1-10.

Okwelle P. C. \& Okeke B. (2012). Development and Validation of Instrument for Assessing Practical Skills in Fault Diagnoses and Repairs of Radio and Television System in Nigerian Technical Colleges: American Journal of Scientific and Industrial Research. 4(12), 67-77.

Rivers State Ministry of Education (NBTE, 2017). Statistics of Teachers and Students in Mechanical Engineering Trades in Government Technical Colleges in Rivers State.

UNESCO \& ILO (2002). Technical and Vocational Education and Training for the Twenty-first Century: UNESCO and ILO Recommendations. UNESCO-UNEVOC Publications. Retrieved from http://www.unesdoc.unesco.org/images/0012/001260/126050e.pdf on 4/11/2017.

Williams, P. S. (2012). Skill Acquisition: A Tool for Youth Development and Empowerment. Being a Paper Presented at the Nigerian Association of Teachers of Technology (NATT) 22nd Annual National Conference, p. 184 - 188. 